\title{
外傷性腓骨筋腱脱臼の治療経験
}

\begin{tabular}{|c|c|c|c|c|c|}
\hline \multicolumn{6}{|c|}{ 松山赤十字病院整形外科 } \\
\hline 荒 井 & 隆 & 志・山 & 本 & & 進 \\
\hline 萩山 & 吉 & 孝・阪 & 田 & 泰 & 二 \\
\hline 瀬 分 & & 厚・若 & 狭 & 雅 & 彦 \\
\hline 原 田 & & 昭・真 & 鍋 & 英 & 喜 \\
\hline 三 浦 & 哲 & 夫 & & & \\
\hline \multicolumn{6}{|l|}{ 平松整形外科病院 } \\
\hline 平 松 & 恵 & 一 & & & \\
\hline
\end{tabular}

\section{Surgical Treatment of Dislocation of the Peroneal Tendon}

by

\section{Takashi Arai, Susumu Yamamoto, Yoshitaka Hagiyama, Yasuji Sakata, Atsushi Sewake, Masahiko Wakasa Akira Harada, Hideki Manabe and Tetsuo Miura \\ Matsuyama Red Cross Hospital.}

Keiichi Hiramatsu

Hiramatsu Orthopedic Hospital.

\begin{abstract}
Five cases of traumatic dislocation of the peroneal tendon which were treated surgically are discussed. The ages ranged from 14 to 26 years with an average age of 18.2 years. All injuries resulted from athletic traumas. In case 1, the DuVries' technique was used, however, dislocation persisted. In case 2, in addition to the DuVries' technique, three holes were drilled into the posterolateral surface of the lateral malleolus and sutures in the retinaculum were pulled through the holes. The retinaculum was firmly attached to the fibula. No dislocation was recognisable. In the other 3 cases (cases 3,4 and 5), only drilling and attachment were performed and all the patients have since resumed their athletic activities.
\end{abstract}

\section{は じめに}

外傷性腓骨筋腱脱曰は，従来，比較的稀な疾患とさ れてきた。 しかし，近年スポーッの一般化に伴なって 報告が增加する傾向にある。また本疾患は，新鮮例で は単なる足関節捻挫として初期治療され，習慣性脱臼 となり診断されることが多い。

今回，我々はスポーツに起因した 5 例を経験し，上 腓骨筋支帯之腓骨筋腱鞘の縫着により良好な結果を得
たので，その手術法とともに若干の文献的考察を加え て報告する。

$$
\text { 症例 }
$$

症例は 5 例で 全例男性, 初診時年令は 14 才から 26 才まで平均 18.2 才であった. いずれあ スポーッ時の 外傷と関連があり, 適切な治療を受けないまま, 習慣 性脱曰となっていた．受傷から手術までの期間は最少 5 週から最長 2 年であった. 手術方法は DuVries 法 
表 1 症 例 内 訳

\begin{tabular}{|c|c|c|c|c|c|c|c|c|}
\hline & 年令 & 性別 & 起因スポーツ & $\begin{array}{l}\text { 受傷 } \\
\text { ま }\end{array}$ & $\begin{array}{l}\text { 手術 } \\
\text { 間 }\end{array}$ & 術 & $\begin{array}{l}\text { 術後目 } \\
\text { 定期間 }\end{array}$ & 再脱且 \\
\hline $\begin{array}{l}1 \\
2 \\
3\end{array}$ & $\begin{array}{l}19 \\
26 \\
16 \\
16 \\
14\end{array}$ & $\begin{array}{l}\text { 男 } \\
\text { 男 } \\
\text { 男 } \\
\text { 男 } \\
\text { 男 }\end{array}$ & 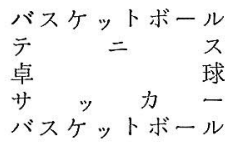 & $\begin{array}{ll}2 & \\
5 & \\
4 & \text { 力 } \\
2 & \text { 力 } \\
2 & \end{array}$ & $\begin{array}{l}\text { 年 } \\
\text { 週 } \\
\text { 命 } \\
\text { 目 } \\
\text { 年 }\end{array}$ & $\begin{array}{l}\text { DuVries 法 } \\
\text { DuVries 法十筋支帯縫着 } \\
\text { 縫 着 の み } \\
\text { " } \\
\text { " }\end{array}$ & $\begin{array}{l}4 \\
6 \\
5 \\
4\end{array}$ & $\begin{array}{l}(+) \\
(-) \\
(-) \\
(-) \\
(-)\end{array}$ \\
\hline
\end{tabular}

1 例, DuVries 法十筋支带縫着 1 例, 縫着のみ 3 例 であった（表 1 ).

症例 $1: 19$ 才, 男性

主訴：左外果部の腱の逸脱感，左外果部㓩

現病歴：以前より，バスケットボールでよく捻挫を 繰り返していた. 2 年前頃より運動時に左外果部に疼 痛を生じたが受傷肢位はよく覚えていない４ケ月前 頃加ら外果部の腱の逸脱感賞えたが放置していた. 次第に疼痛のため階段を昇るのが困難となり，当科を 受獄した。

初彰時所見：左外果部に圧痛を認め，左足関節を背 屈させると腓骨筋腱が外果後方より皮下へ膨隆すると とも疼痛を訴えた。

治療経過：手術時，上腓骨筋支帯は弛緩していたが 断裂は認められず，外果付着部後方より剶離している のが観察された。腱鞘は肥厚し, 短腓骨筇は筋部が腱 溝を通り末梢まで認められた. DuVries 法に従い, 骨片をやや多比 $10 \mathrm{~mm}$ 後方へ slide させ, 1.5 cm の screw にてての骨片を固定した. 術後 2 年の 現在, 日常生活に不安はないが, スポーッ時に数度の 再脱臼を認名てい。.

症例 2:26才, 男性

主培：歩行時の右外果部痛

現病歴：約 1 ケ月前テニス中に在足関節を背屈回外 強制され, 弾発音とともに右外果部に疼痛之腫脹が出 現し, 近医にて湿布のみ受けた. 次第に歩行時の右外 果部痛が增強してきたため, 当科を受䛦した。

初診時所見: 局所の腫脹・圧痛は認めないが, 右足 関節を背屈させつつ腓骨筋腱部を後方より圧すると, 筋腱は容易に脱臼した。

治療経過: 手術時, 上腓骨筇支带は弛緩・伸張し, 外果の前方まで㓦離されており，足関節を外がえしさ せると長腓骨笳腱は容易に脱且した. DuVries 法に 加え, さらに外果後縁に 3 ケ所 drilling を行ない, 上腓骨筋支帯と腓骨筋腱鞘部を 2-0 nylon 系でその

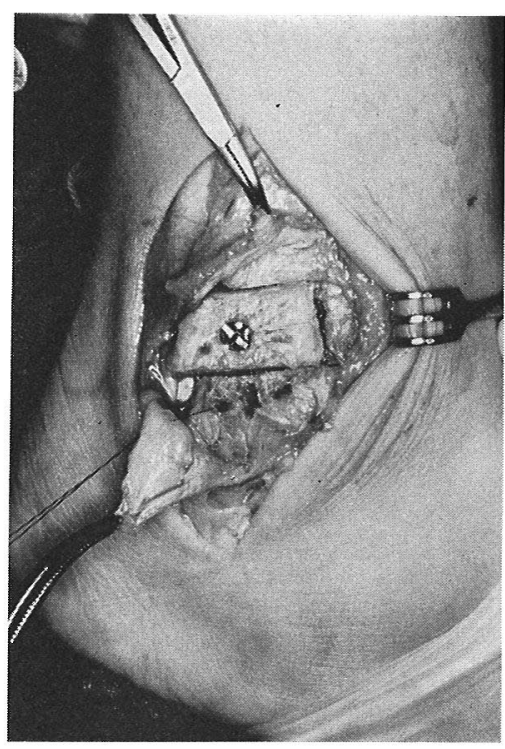

図1症例 26 才, 男

(Duvries 法十支帯縫着術)

部に強固に縫着した（図1）。

術後 6 週間ギプス固定. 現在まで脱曰の再発は認め られない，受傷以前と同様にスポーツを楽しんでい る.

症例 $3: 16$ 才, 男性

主訴：スポーツ時右外果部痛

現病歴：4 ケ月前卓球中右足を踏んばり，右足関節 を背屈強制され，外果部に激痛を生じた，自宅で湿布 をして様子をみていたが，スポーッ等で疼痛とともに 外果部に怙ける索状物の滑脱があるため，近医受部 し，当科を紹介された。

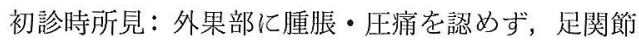
背屈にて 容易に 腓骨筋腱が 脱臼するのが観察された (図2).

治療経過：乙の症例に対しては筋支带上腱鞘の縫着 のみを行なった. 腓骨後縁約 $0.5 \mathrm{~cm}$ の所で拡張した 

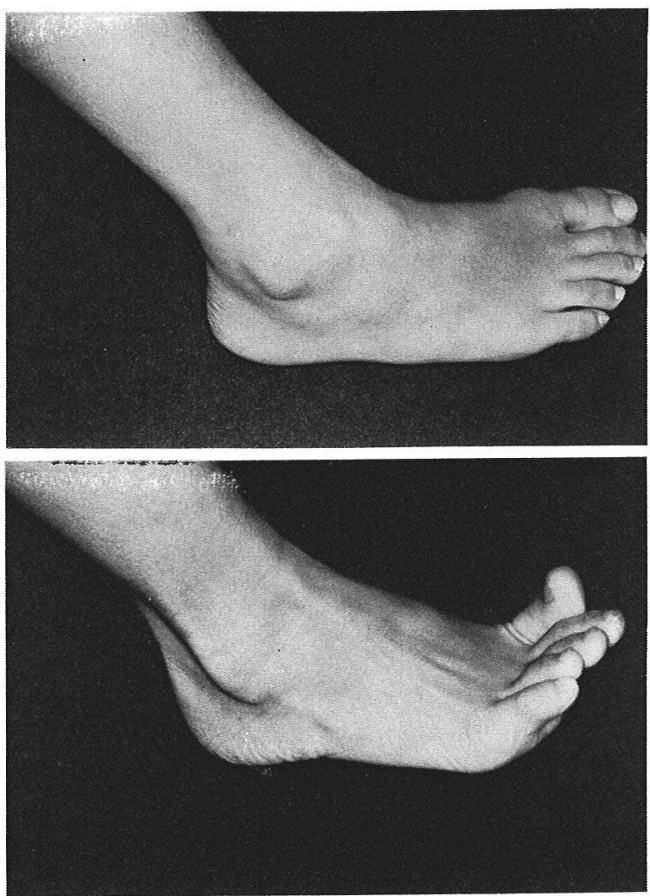

図 2 症例 3 16才，男

上段 底属位

下段 背屈位で外果に索状物の膨隆を認める （随意性脱臼）

筋支帯を縦切した後, $2 \mathrm{~mm}$ キルシュナー鋼線を通 して外果後方に3 ケ所穴をあけた。そして 2-0 nylon 系を用いて 拡張した筋支帯と腱鞘とを同時に縫着し た. 前方の剝離された支帯の切離端は，その上に overlapさせた (図3).

術後 2 年の現在再脱臼は認められない，症例 4,5 に対しては症例 3 と同じ術式を行ない, 全例スポーツ に復帰し，再脱臼は認められない。

考 察

外傷性腓骨筋腱脱臼の 発生機序として, Stover ${ }^{12)}$ は，急激かつ強力な背届と内反の強制により腓骨筋の 強い反射性収縮が誘発され起こるとした．さらに腱保 持機構の抵抗以上に反射性収縮が強力ならば外反位で も生じうるとした，Marti ${ }^{8)}$ も肢位と無関係に起こり うると述べている．自験例は全例筋力旺盛な若年男性 で，うち３例は受傷時背屈を強制され，2 例は肢位不 明であった. また手術時腱溝及び外果外縁隆起の形成 は良好であった，乙の所見は，強力な筋収縮が存在す
れば腱溝の形態の如何を問わず脱且が起こりうるとと を示唆している。

Eckert ${ }^{3)}$ は，スキーによる 73 例の 新鮮腓骨筋支 帯損傷を術中所見により以下の如く 3 段階に分類し,

Grade 1）支帯は collagenous lip 及び外果から 䟝離されている。

Grade 2) 外果後縁の collagenous lip の遠位部 が支帯とともに剝離されている.

Grade 3) collagenous lip に沿う溥い骨片を伴な っている.

そして筋支帯自体の断裂は1例もみられなかったと 述べている.この collagenous Iip は, 外果後外緣 にみられる 3〜 $4 \mathrm{~cm}$ 長の軟部組織隆起で, 肉眼では 線維軟骨様であり，顕微鏡下では膠原線維の集合体で ある. また渡辺 ${ }^{13)} ら は$ 脱臼直接原因を，支带完全 断裂型と支帯付着部剝離型の 2 型に分類している. 自験例は全例支带付着部剝離型であり, Eckert の Grade 1) に相当する初期損傷があったものと推察で きる。

診断は，新鮮例では血腫及び腫脤のため，しばしば 単なる捻挫としてみすごされることが多く，また臨床 的に他の足部外傷との鑑別が困難である場合む多い. 習慣性脱臼の場合は自・他覚的な脱臼の証明により容 易である.

治療は，新鮮例ではまず保存的療法を試みるべきで あるとされているが，習慣性に移行する例が多いよう である。本格的なスポーツ選手の場合は観血的治療 が考慮され，特に剝離骨折を伴なう時は適応といえ $ろ^{10)}$. 習慣性脱臼の場合は観血的治療が必要とされ, 胃性制動法之支带形成術に大別されるが，我々は図 4 の如く, 症例 $3 ， 4 ， 5$ に対して支带と腱鞘を外果後 縁に縫着する術式を行なった，軟部組織縫合の場合縫 合部の弛緩や伸長を起とし易く，新たな外傷による再 断裂の危険があるとされている ${ }^{6)}$ が, 支带付着部の剝 離のみで筋支帯の変性・萎縮・瘷痕が少ない場合は, 我々の縫着・縫縮のみで充分脱臼が阻止されるものと 思われる. 症例 1 は DuVries 法を行ない術後再脱臼 を認めた。乙の症例では長・短腓骨筋腱は肥大し, 短 腓具筋の筋束部が支帯末梢まであり，強い筋収縮の結 果長腓骨筋腱が押し出され再脱臼したものと考えた. このような症例に対しては骨スライドの幅の増量或い は他の支带形成術との併用も考慮す心゙きであろう。 


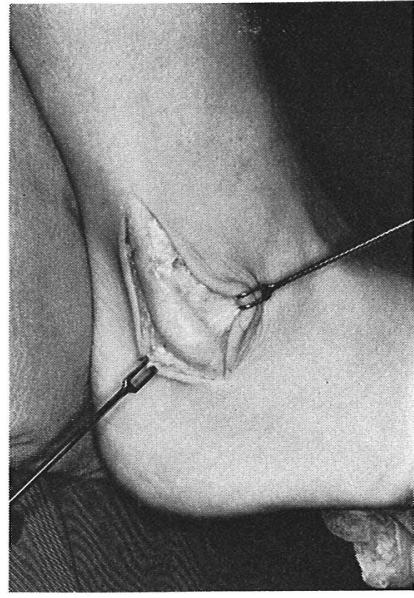

a．脣腓骨筋腱は滑脱して前方へ脱曰乙ている。

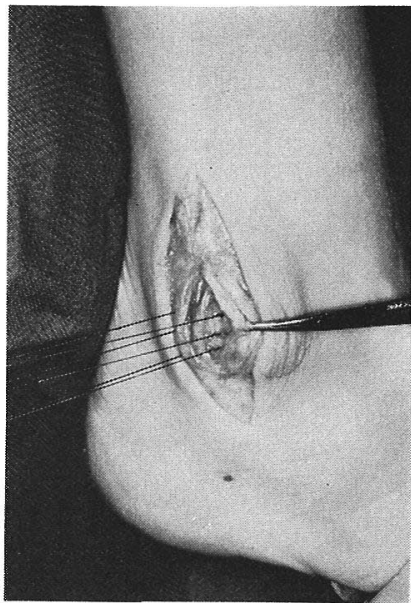

c、拡張した筋支帯と腱靬を縫着する。

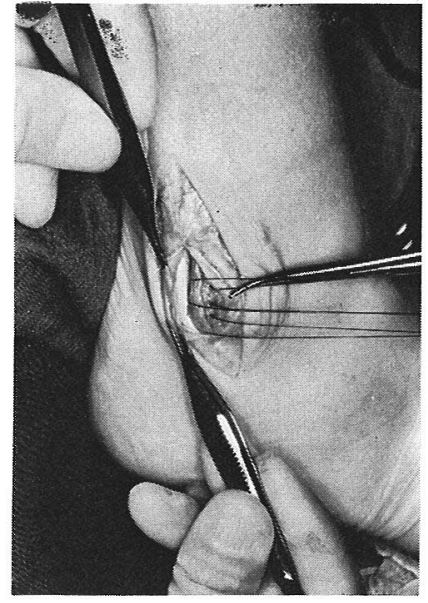

b. 外果後縁 3 ケ所に穴をあけ，2-0ナイロン糸 を通す。

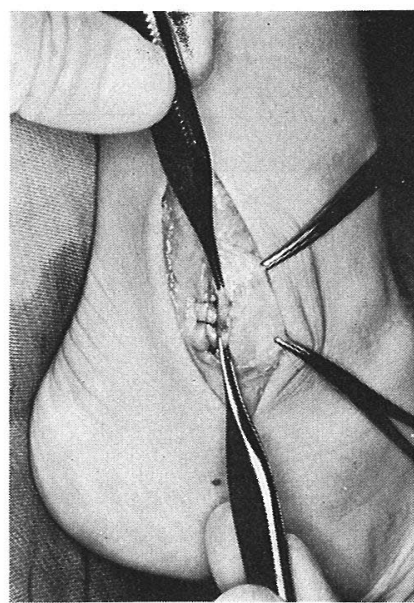

d．前方の㔀離された支帯を重ねあわせる。

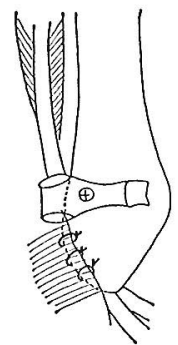

腚例 2

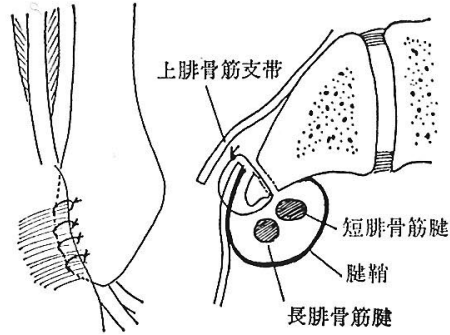

症例 $3,4,5$
ま と め

1） 5 例の外傷性腓骨筇腱脱曰を 経験し， 1 例に DuVries 法を, 1 例に DuVries 法に加えて支帯縫 着術を，3例に支帯縫着術のみを行なった。

2) DuVries 法を行なった 1 例に再脱臼を認めた が，他の 4 例は再脱臼もなく元のスポーツに復帰して いる.

3）本症例にみられた支帯付着部剝離型に対して, 支帯縫着法は有効な術式であると思われる。

図4術式のシェーマ 
文

献

1) Alm, A.: Surgical treatment of dislocation of the peroneal tendons. Injury, 7 : 14-19, 1975.

2) Beck, E.: Operative treatment of recurrent dislocation of the peroneal tendons. Arch. Orthop. Trauma. Surg., 98: 247-250, 1981.

3) Eckert, W. R. : Acute rupture of the peroneal retinaculum. J. Bone and Joint Surg., 58-A : 670-673, 1976.

4) Gurevitz, S. L. : Surgical correction of subluxing peroneal tendons with a case report. Journal of the American Podiatry Association, 69: 357-363, 1979.

5）原浩史 - 他：外傷性腓骨筋腱脱曰の治療経 験. 中部整災誌, 26: 1862-1864, 1983.

6）岩原寅猪 - 他：習慣性腓骨筋腱脱曰. 整形外
科, 16: $222-232,1965$ 。

7）北田 力 - 他 : 腓骨筋腱脱曰について。臨整 外, 12: 1140-1152, 1977 .

8) Marti, R: Dislocation of the tendons. Am. J. Sports Med., 5: 19-22, 1977.

9）益子秀久 - 他：外傷性腓骨筋腱脱目 5 例の治療 経験。整形外科, 34: 1197-1200, 1983.

10) McLennan, J. G.: Treatment of acute and chronic luxations of peroneal tendons. Am. J. Sports Med., 8: 432-436, 1980.

11）中野謙吾 - 他：腓骨筋腱脱曰について。整形外 科, $22: 212-220,1971$.

12) Stover, C. N.: Traumatic dislocation of the peroneal tendons. Am. J. Surg., 103: 180-186, 1962.

13）渡辺省二・他：外傷性腓骨筋腱脱曰の1例．臨 整外, 17: 933-936, 1982. 